\title{
Simple and efficient approach for shelf-life test on frozen spinach and parsley
}

\author{
Eleonora Iaccheri, ${ }^{1}$ Chiara Cevoli, ${ }^{1,2}$ Santina Romani,,${ }^{1,2}$ Marco Dalla Rosa,,${ }^{1,2}$ Giovanni Molari, ${ }^{2}$ \\ Angelo Fabbri ${ }^{1,2}$ \\ ${ }^{1}$ Interdepartmental Centre for Agri-Food Industrial Research, Alma Mater Studiorum, University of Bologna; \\ ${ }^{2}$ Department of Agricultural and Food Science, Alma Mater Studiorum, University of Bologna, Bologna, Italy
}

\begin{abstract}
A simple test for shelf-life assessment of frozen spinach and parsley is presented. A specific shelf-life test that considers three storage temperatures is proposed to accelerate the rate of quality decay in frozen spinach and parsley. The scope was to provide a reliable and rapid way (one month $v s$ years) to predict shelf-life by using a simple experimental approach and mathematical models based on some physical quality product attributes. Physical properties were evaluated at three storage temperatures: $-5^{\circ} \mathrm{C},-10^{\circ} \mathrm{C}$ and $-26^{\circ} \mathrm{C}$, to simulate a possible thermal abuse. Mechanical and thermal indexes were defined measuring maximum compression force $(\mathrm{N})$ and latent heat involved in ice melting $(\mathrm{J} / \mathrm{g})$. A zeroorder kinetic model was used to properly fit experimental data and thus to obtain related reaction rates. The determination coefficient indicates that there is a strong linear relation between kinetic parameters at $-10^{\circ} \mathrm{C}$ or $-5^{\circ} \mathrm{C}$ and $-26^{\circ} \mathrm{C}$. This suggests a reliable procedure for shelf-life estimation, carrying out a test at $-10^{\circ} \mathrm{C}$ or $-5^{\circ} \mathrm{C}$ for one month and extending values to data acquired at $26^{\circ} \mathrm{C}$ for the same period of time. The relations obtained from this research have led to a simple practical approach: one day at $-10^{\circ} \mathrm{C}$
\end{abstract}

Correspondence: Chiara Cevoli, Interdepartmental Centre for AgriFood Industrial Research, Alma Mater Studiorum, University of Bologna, viale Fanin, Bologna, Italy. E-mail: chiara.cevoli3@unibo.it

Key words: Frozen vegetables; shelf-life test; physical attributes; thermal and mechanical properties; simple mathematical model.

Acknowledgements and funding: this work was supported by the Coach project - Cold management in Agro-food Chains: solutions for process digitalization (Grant number (CUP): CUP D41F18000060009), cofunded by the Emilia-Romagna Region through the POR FESR 2014e2020 funds (European Regional Development Fund).

Conflict of interests: the authors declare no potential conflict of interests.

Received for publication: 10 May 2021.

Accepted for publication: 28 July 2021.

(c) Copyright: the Author(s), 2021

Licensee PAGEPress, Italy

Journal of Agricultural Engineering 2021; LII:1199

doi:10.4081/jae.2021.1199

This article is distributed under the terms of the Creative Commons Attribution Noncommercial License (by-nc 4.0) which permits any noncommercial use, distribution, and reproduction in any medium, provided the original author(s) and source are credited. could be considered roughly equivalent to 30 days at $-26^{\circ} \mathrm{C}$. Accordingly, it could be possible to obtain a shelf-life estimation in short time, also considering other similar products.

\section{Introduction}

Frozen product design involves the freezing system selection and its impact on food properties. Incorporating quality of frozen product into production/process design is still a challenge for food manufacturer. Product and process design need to be flexible, and quality obtained by trial and error does no longer seem to be the best approach (Van Boekel, 2008).

Shelf-life estimation for such products is difficult as well. In this industry durability is generally estimated by accelerated tests in order to be market competitive and to reduce time and costs (Modarres et al., 2017; Mattetti et al., 2019). The food industry still has a significant need of collecting useful information in the shortest possible time for product shelf-life estimations (Mizrahi, 2011).

Freezing agricultural products is a process which triggers transport phenomena and significant and irreversible changes in their microstructure and chemical-physical properties and affects their quality, stability, shelf-life extension, and market value (Góral and Kluza, 2009; Alabi et al., 2020). In particular, physical properties such as density, thermal conductivity, specific heat, thermal diffusivity, and hentalpy are important for process management and quality control (Van Boekel, 2008). Collecting data on the principal parameters describing the senescence and the kinetics rates of quality decay may contribute to shelf-life assessment. Therefore, the knowledge of physical properties of frozen foods is of utmost importance during storage, when complex reactions could accelerate food degradation.

Shelf-life can be defined as the finite length of time after production and packaging, during which the product retains an acceptable level of quality under well-defined storage conditions (Taoukis and Giannakourou, 2018). Although this term is frequently used due to its practical applicability, the definition of acceptable level is inaccurate and the definition of acceptable level is inaccurate and leave possibility to introduce subjective evaluations (Taoukis and Giannakourou, 2018). The storage time of frozen products is very long compared to other food products. As a consequence, for practical reasons, accelerated tests are carried out as a capable tool for shelf-life assessment (Mizrahi, 2011).

Considering frozen vegetables, storage temperature is a key factor for the quality decay kinetics, and therefore for accelerated stress testing. The main component of fruits and vegetables is water (content of up to $80-90 \%$ ) that can influence microbial activity, enzymatic reactions and the microstructural changes 
which depend on cell size, cell composition including water and gases, freezing conditions and pressure gradient generated within the cell (Alabi et al., 2020). Different temperature-related kinetic behaviours may be used to describe the predominant phenomena which impact shelf-life.

Frozen foods are thermodynamically unstable also at low temperature and take a long time before reaching a balance. An example of quality evolution for parsley was reported by Iaccheri et al. (Iaccheri et al., 2021). Due to food physical complexity in terms of thermodynamic behaviour, empirical models were often applied to describe properly measured parameters (Dermesonluoglu et al., 2015). However, despite the real conditions, time-temperature fluctuations of the whole food chain are the main product weakness, as they are difficult to be assessed precisely. In this way it is possible to attempt a shelf-life calculation based on theoretical background data at different isothermal conditions (Taoukis and Giannakourou, 2018).

A widely accepted way to assess food shelf-life considers the measurement of representative quality indices as a function of storage time at selected temperature and humidity $(\mathrm{RH})$ environmental conditions (Van Boekel, 2008). The critical part in this first step is the choice of quality parameters. Frozen vegetables degradation is generally described by nutritional content loss, deterioration of sensory attributes (colour, flavour/aroma, taste), off-flavour development, pigment and colour degradation, oxidative deterioration, vitamin loss, moisture migration, ice recrystallization, texture and drip loss (Giannakourou and Taoukis, 2019).

The second step involves the selection of appropriate mathematical equations that can properly describe the changes of selected quality indices over time. This step is still a challenge considering the complex behaviours of degradation phenomena in food. Well known chemical kinetics is based on elementary reactions, while many interactions involved in the foodstuff are rather complex (Van Boekel, 2008).

Storage temperature is the most widely used environmental factor in most research works carried out to estimate food shelflife. Indeed, tests are performed by studying a deterioration process at different temperatures (higher than real storage temperature), therefore, the measurement of the rate of quality depletion at higher temperatures makes it possible to extrapolate the reaction rate at a desired storage temperature and consequently to predict the shelf-life (Fu and Labuza, 1997; Martins et al., 2005; Correa et al., 2015; Li et al., 2020). Concerning the frozen foods, reported common temperatures for accelerated shelf-life testing are $-5,-10$, -15 and $-18^{\circ} \mathrm{C}$ (Labuza and $\mathrm{Fu}, 1993$; Fu and Labuza, 1997).

Different relationships between frozen food shelf-life and temperature, both at variable and constant temperature storage conditions, have been reported in literature. The frozen products which were have been already investigated are salmon, mackerel, pork meat, ice cream, pizza, hollandaise sauce, strawberries, and broccoli (Gormley et al., 2002), strawberries (Sahari et al., 2004), potatoes (Ullah et al., 2014), spinach (Dermesonluoglu et al., 2015), shrimp (Tsironi et al., 2009), carrots (Vicent et al., 2019; Gonçalves et al., 2020). Despite the amount of literature regarding shelf-life prediction of foods, to our knowledge there are no studies on the application of rapid methods for the assessment of frozen product shelf-life using physical parameters. The aim of this research is to test a possible simple and efficient approach to quantify the shelf-life of both frozen spinach and parsley in a very short time.

\section{Materials and methods}

\section{Samples}

Frozen parsley and spinach were supplied directly at the end of the production process by a manufacturer involved in the research project. Parsley contained maximum 3\% of sunflower oil and spinach was cube-shaped, as conventionally prepared by company. Samples, packed in a polyethylene (LLDPE, $60 \mathrm{my}$ ) bag of about $10 \mathrm{~kg}$ of product, inside a cardboard secondary package, were stored at three different isothermal conditions: $-5^{\circ} \mathrm{C},-10^{\circ} \mathrm{C}$ for 24 days, and at the real storage conditions of $-26^{\circ} \mathrm{C}$ for 24 months (directly at the producer warehouse). The temperatures of $-5^{\circ} \mathrm{C}$ and $-10^{\circ} \mathrm{C}$ were selected to investigate product quality evolution under stress conditions, and to understand product behaviour due to the typical temperature fluctuations occurring along the cold chain. These temperatures are the most widely used in order to perform shelf-life testing of frozen products in isothermal conditions (Labuza and Fu, 1993; Fu and Labuza, 1997).

Three packages (replicates) of each type of sample and storage temperature were collected at selected time periods and the products were analysed after thawing at environmental (ambient room $\left(22^{\circ} \mathrm{C},+-1{ }^{\circ} \mathrm{C}\right)$ temperature for about $3 \mathrm{~h}$.

\section{Mechanical properties}

The mechanical properties of thawed samples at each storage temperatures were analysed by using a texture analyser Zwick Roell (series Zwickline Z 2.5; Ulm). Preliminary tests were carried out to identify a set of ideal conditions (for example, tool feasibility and test speed).

For spinach cube samples, a compression test was performed by means of a cylindrical tool $(f 60 \mathrm{~mm})$ and a load cell (F.S. 500 $\mathrm{N})$. The test speed was $1 \mathrm{~mm} / \mathrm{s}$ and $80 \%$ of deformation was set for

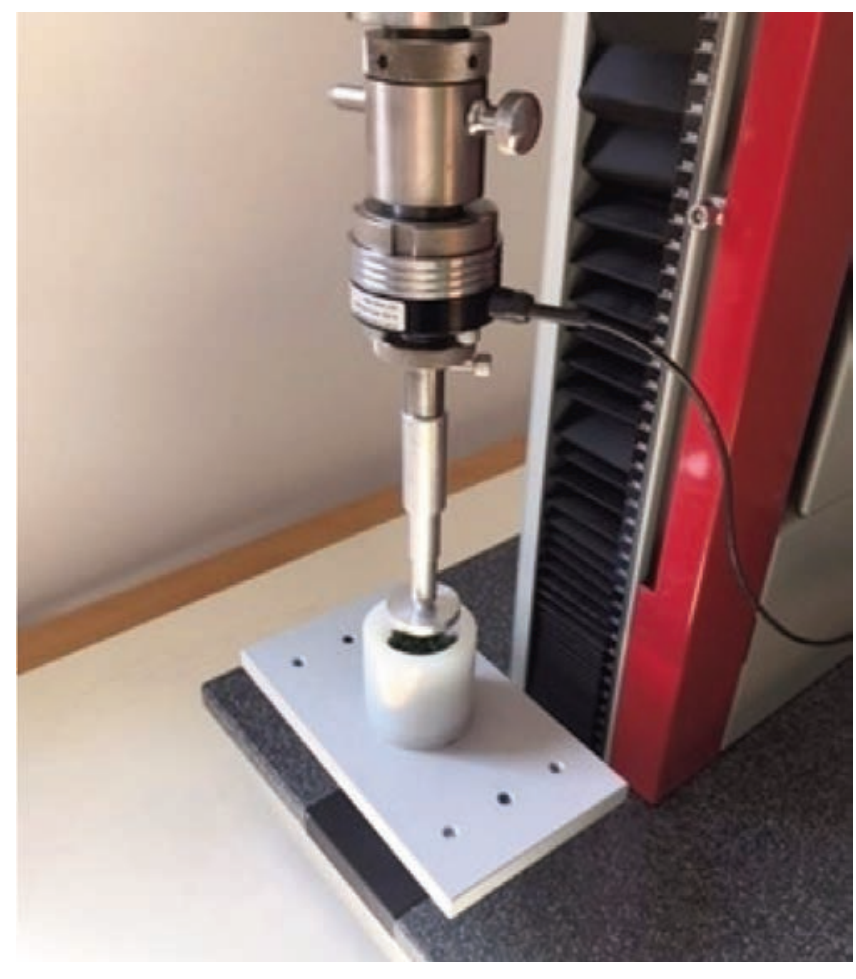

Figure 1. Back extrusion test carried out on parsley. 
test end, because spinach cubes had a different height.

Data were acquired with a resolution of 830 points/s. Spinach cubes were weighted and were $65.3( \pm 9.7), 67.5( \pm 9.2)$ and 62.7 $( \pm 11.4)$ grams for $-5^{\circ} \mathrm{C},-10^{\circ} \mathrm{C}$ and $-26^{\circ} \mathrm{C}$ respectively. Parsley was investigated by using the same load cell carrying out a back extrusion test with a cylindrical container $(f 64 \mathrm{~mm})$ filled with 20 $\mathrm{mm}$ of samples and a plate $(f 60 \mathrm{~mm})$ (test speed $1 \mathrm{~mm} / \mathrm{s}$ ) (Figure 1). At least 10 measurements were carried out for each thawed sample at ambient temperature $\left(23 \pm 1^{\circ} \mathrm{C}\right)$. For both tests, the maximum force at defined deformation $(\mathrm{N})$ was extrapolated.

\section{Thermal properties}

Both for spinach and parsley, the melting point of ice was considered as the initial and final freezing point. The related heat of fusion $(\mathrm{J} / \mathrm{g})$ was evaluated in triplicate by using a differential scanning calorimeter (DSC) mod. Q20 (TA Instrument, Germany). DSC was interfaced with a cooling unit mod. System90 (TA Instrument, Germany) able to reach a minimum temperature of $90^{\circ} \mathrm{C}$. Different calibrations were performed, the same heating rate used for sample measurement was applied under a dry nitrogen gas flux $(50 \mathrm{~mL} / \mathrm{min})$, and the heat of fusion of indium $(\Delta \mathrm{H} 28.71 \mathrm{~J} / \mathrm{g})$ was used to gauge the heat flow. Each sample (about $10 \mathrm{mg}$ ) was weighed in hermetic aluminium pans, and then loaded into the DSC instrument at room temperature, using an empty pan for reference. Samples were equilibrated at $-35^{\circ} \mathrm{C}$ for $30 \mathrm{~min}$, and then two heat-cool cycles were applied from -90 to $80^{\circ} \mathrm{C}$ at $5^{\circ} \mathrm{C} / \mathrm{min}$. This method was applied on the basis of preliminary trials carried out on the same samples. Thermograms were evaluated by using the Software TA-Universal analyser (TA Instrument, Germany). Each sample at each storage time was acquired in triplicate.

\section{Statistics and mathematical models}

For each storage temperature, linear regressions were used to describe the evolution of the selected quality parameter ( $A=$ quality parameter mean values on three replicates) over the time $(t)$.

The root mean square error (RMSE) was used to describe the error in the models presented (Eq. 1):

$$
R M S E=\sqrt{\frac{\sum_{i=1}^{N}\left(x_{i}-\hat{x}_{i}\right)^{2}}{N}}
$$

where $\hat{x}_{i}$ are the predicted values, $x_{i}$ the observed values, and $N$ is the size of samples.

Consequently, zero-order kinetics was used (Eq. 2) to derive the reaction rate $(k)$ from the slope of the linear regression (Eq. 3):

$$
\frac{d A}{d t}=k
$$

$A=A_{0}+k \cdot t$

indicating how much the initial value $A_{0}$ of the considered quality parameter changed over time. The extent of reaction could be used to calculate the products shelf-life as follows:

$$
t_{s}=\frac{A_{t s}-A_{0}}{k}
$$

where $t_{s}$ is the he shelf-life-time, $A_{t s}=A(t s)$ the limit value of the quality parameter at the end of shelf-life, $A_{0}$ the parameter value at time 0 and $k$ the reaction rate for the zero-order reaction. $A_{t s}$ was evaluated as the parameter measured at the end of the standard storage condition $\left(-26^{\circ} \mathrm{C}\right)$.

Temperature dependence of physical reactions was defined in terms of $Q$-index. This is often reported as $Q 10$, which is the ratio between the reaction speed values related to two temperatures differing by $10^{\circ} \mathrm{C}$ (Myer, 2016). However, the $Q$-index could be used also for other temperature ranges calculated as follows:

$$
Q_{\mathrm{A} k}=\left(\frac{k_{2}}{k_{1}}\right)^{\left(\frac{10^{\circ} C}{T_{2}-T_{1}}\right)}
$$

where $\mathrm{A}_{\mathrm{A}}=\mathrm{T}_{2}-\mathrm{T}_{1}\left({ }^{\circ} \mathrm{C}\right), k_{1}$ and $k_{2}$ are the kinetic reaction rates at temperatures $T_{1}$ and $T_{2}\left({ }^{\circ} \mathrm{C}, \mathrm{T}_{2}>\mathrm{T}_{1}\right)$ (Myer, 2016).

Alternatively, $Q$-index could be calculated as a function of shelf-life time $\left(t_{s}\right)$ obtained at two different temperatures, as follows (Fu and Labuza, 1997):

$$
Q_{\mathrm{A} t s}=\left(\frac{t_{s_{1}}}{t_{s_{2}}}\right)^{\left(\frac{10^{\circ} \mathrm{C}}{T_{2}-T_{1}}\right)}
$$

\section{Results and discussion}

Spinach and parsley were characterized in terms of mechanical and thermal properties in order to assess their quality decay during storage. Accelerated shelf-life tests were conducted at $-5^{\circ} \mathrm{C}$ and $10^{\circ} \mathrm{C}$ storage temperatures and at $-26^{\circ} \mathrm{C}$ as the real storage condition. Mean curves of compression force-deformation for spinach and parsley samples stored at $-26^{\circ} \mathrm{C}$ for different times are shown in Figures $2 \mathrm{~A}$ and $\mathrm{B}$ respectively.A maximum force increase was observed during storage time in both samples, also when stored at higher temperatures. This mechanical behaviour was previously reported for frozen spinach by other authors (Dermesonluoglu et al., 2015). The force increase could be due to moisture loss after thawing from the product surface, which creates an increasingly dry and tough tissue with storage time (Telis et al., 2006).

The thermal profiles of spinach and parsley stored at the selected temperatures were assessed during storage time. Observed endothermic peaks of ice fusion are shown for both products in Figure 3. Figure 3 shows a general increase of the dimension of the melting peak of ice with time for the samples stored at $-26^{\circ} \mathrm{C}$. The area under the curve increased with storage time as a consequence of the heat needed for ice melting. Accordingly, ice crystals became bigger over the storage time, mainly at the highest frozen temperature. The thermodynamics of the ice crystal tends to create a bigger and more stable crystal more stable, but this causes damages to the food structure, which is generally recognized after thawing process (Fu and Labuza, 1997; George and Gormley, 2000; Roos, 2012; Li et al., 2020). Mechanical and thermal data describe physical properties of the products in different way, but they are connected and converge in the same thermodynamic modifications. Bigger ice crystals induce bigger damages in food structures. This phenomenon is evident after thawing, where a larger amount of water causes a high moisture loss, which is the main factor affecting mechanical properties. Both considered mechanical and thermal parameters were able to describe the trend of product degradation during storage time at different temperatures. Chemical deteriorations in foods during storage are generally recognized in a zero or first order kinetics reactions (Mizrahi, 2011), while the changes of physical characteristics can follow different 
reaction orders in relation to the specific parameter and product matrix observed. In this way, our evaluation was based on the experimental data. Both for mechanical and thermal tested charac- teristics of both frozen spinach and parsley samples, a zero-order kinetic model was applied, as shown in Figures 4-7, where mean values and standard errors of recorded data are reported.
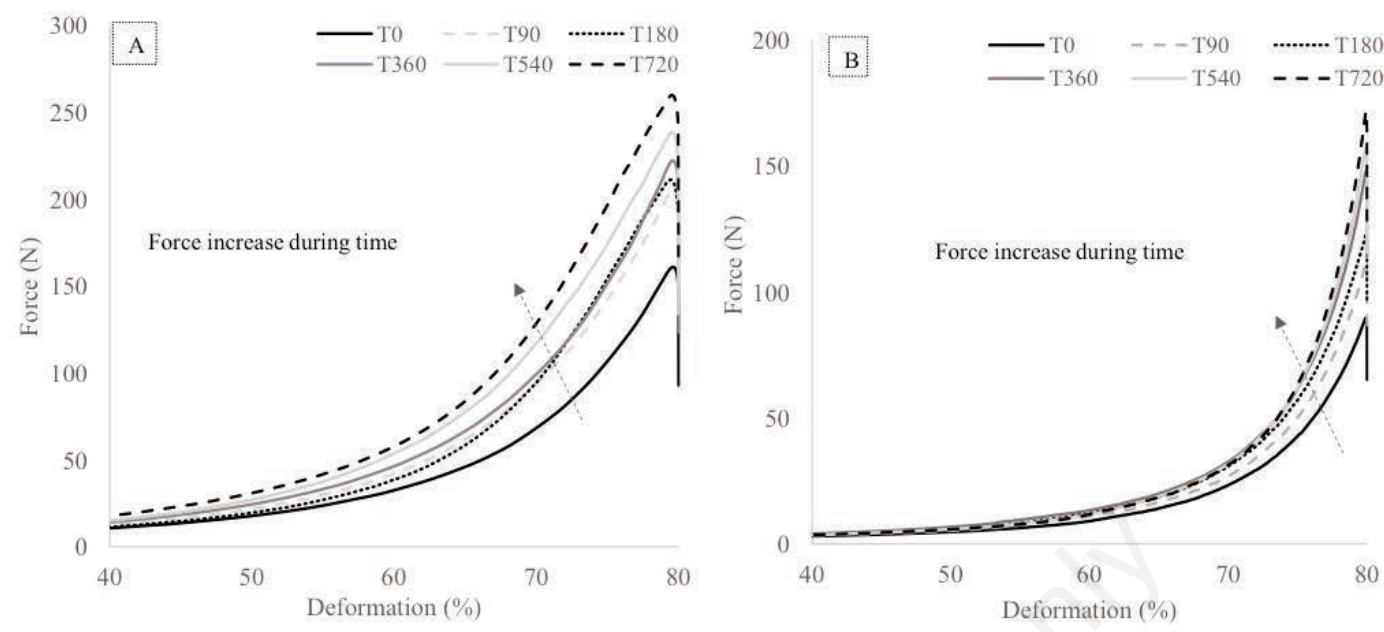

Figure 2. Mean force-distance curves of spinach (A) and parsley

(B) samples stored at $-26^{\circ} \mathrm{C}$ as a function of time (0-720 days).
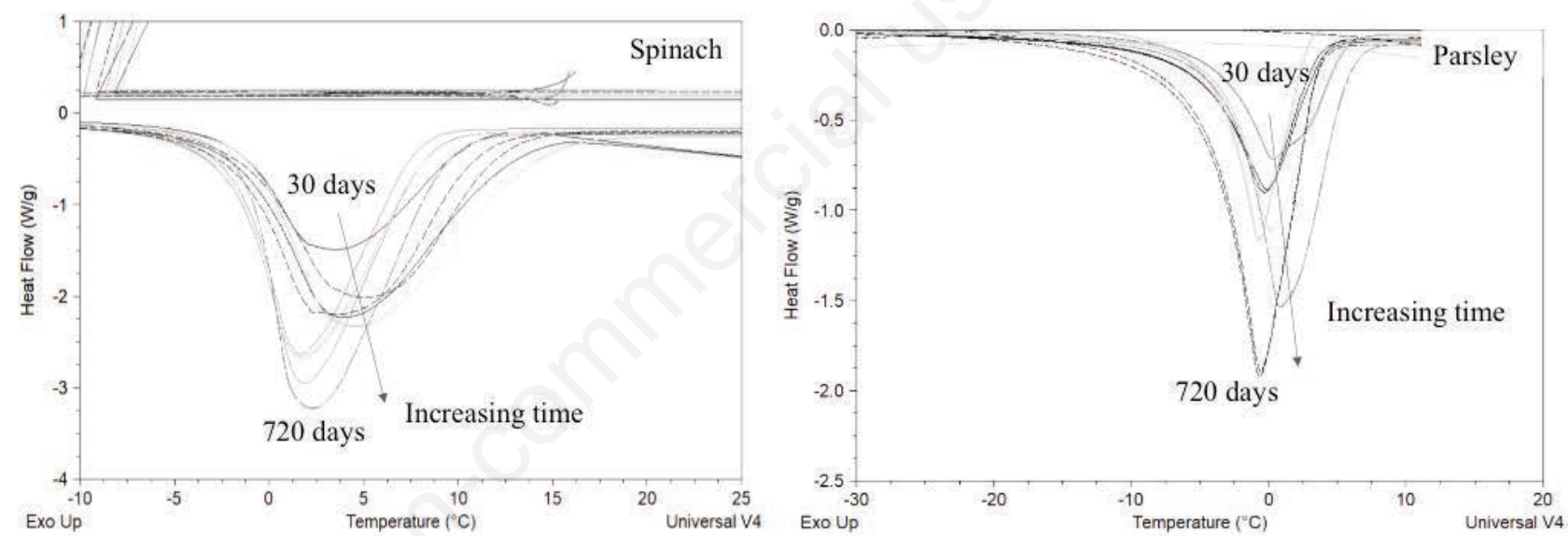

Figure 3. Endothermic peak of ice melting of spinach and parsley samples during storage time, referred to spinach and parsley samples stored at $-26^{\circ} \mathrm{C}$.
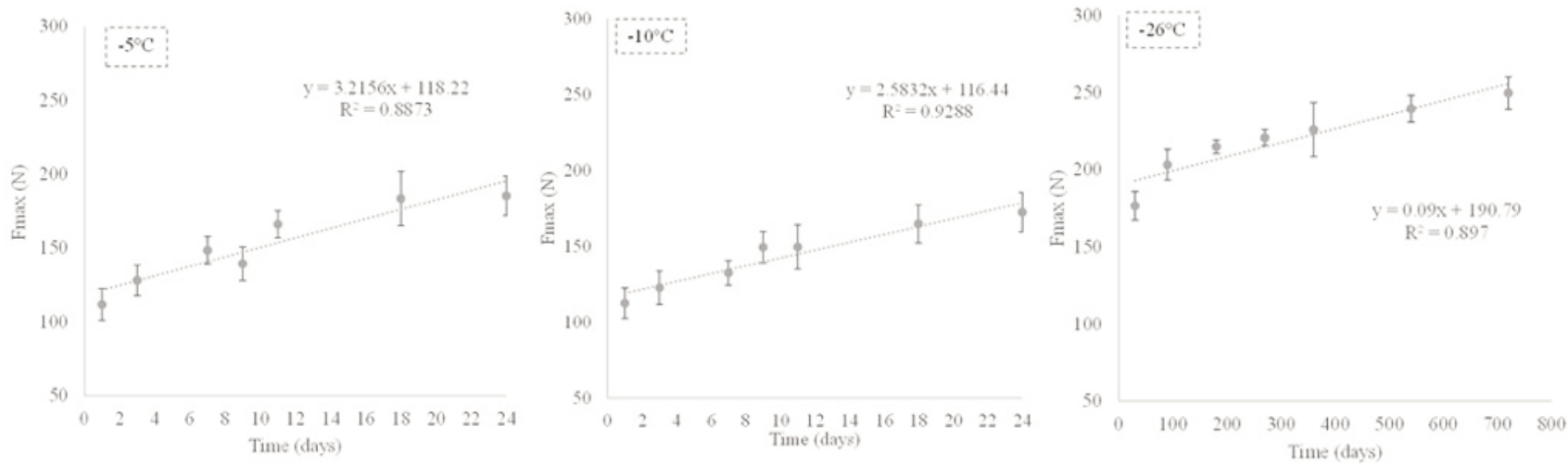

Figure 4. Maximum force (N) kinetics of spinach samples as a function of storage time and temperatures $\left(-5^{\circ} \mathrm{C},-10^{\circ} \mathrm{C},-26^{\circ} \mathrm{C}\right)(\mathrm{p}-\mathrm{level}$ of coefficients $<0.05$, p-level of correlations $<0.01)$. 
The fitting goodness of the applied linear model was evaluated on the basis of the determination coefficient $\left(\mathrm{R}^{2}\right)$ and RMSE and were reported in Table 1.

Good model performances, in terms of the highest coefficients of determination of 0.954 and 0.947 , were obtained from the heat fusion data modelling of spinach stored at $-26^{\circ} \mathrm{C}$ and parsley stored at $-5^{\circ} \mathrm{C}$, respectively. It should be noted that the lowest $\mathrm{R}^{2}$ was 0.833 , confirming good data interpolation by linear fitting. In
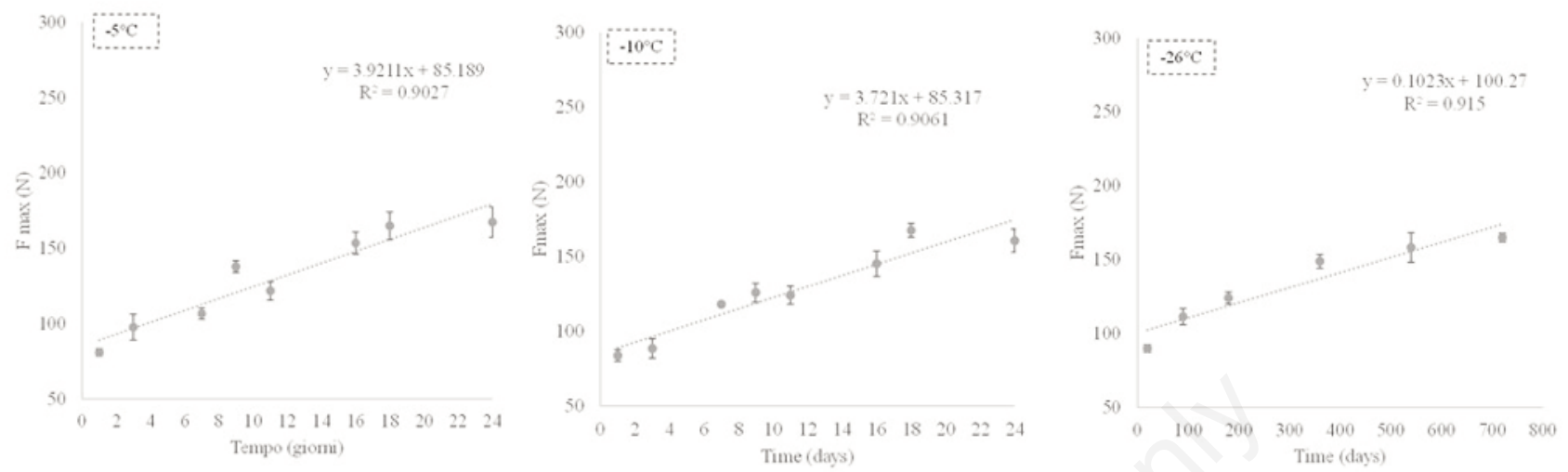

Figure 5. Maximum force $(\mathrm{N})$ kinetics of parsley samples as a function of storage time and temperatures $\left(-5^{\circ} \mathrm{C},-10^{\circ} \mathrm{C},-26^{\circ} \mathrm{C}\right)(\mathrm{p}-\mathrm{level}$ of coefficients $<0.05$, p-level of correlations $<0.01)$.

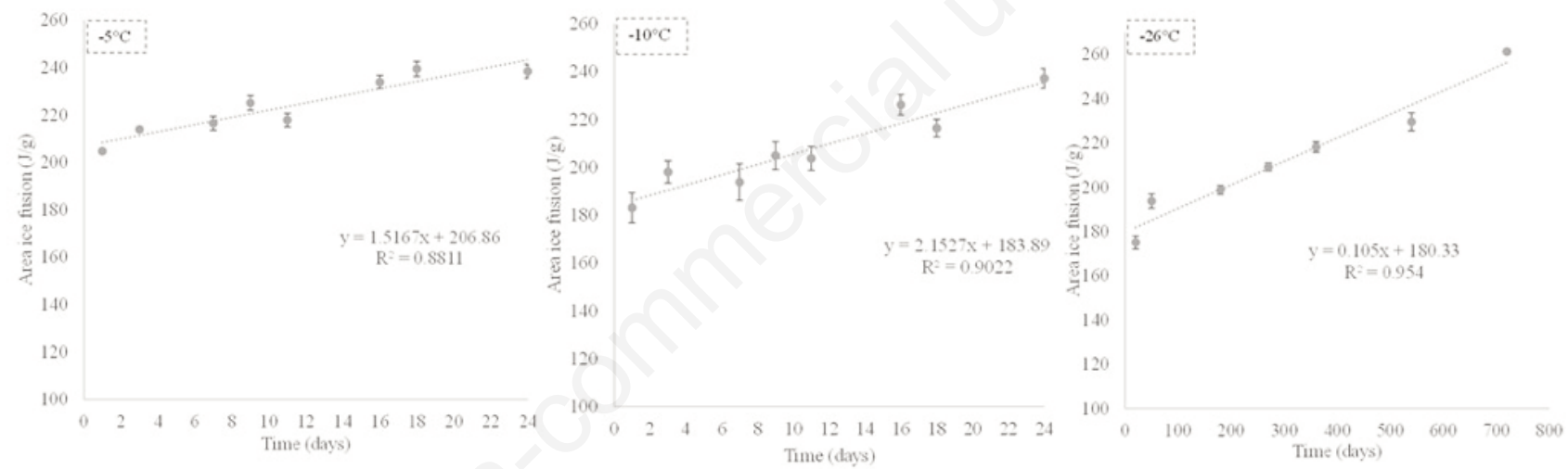

Figure 6. Heat of ice melting $(\mathrm{J} / \mathrm{g})$ kinetics of spinach samples as a function of storage time and temperatures $\left(-5^{\circ} \mathrm{C},-10^{\circ} \mathrm{C},-26^{\circ} \mathrm{C}\right)(\mathrm{p}-$ level of coefficients $<\mathbf{0 . 0 5}$, p-level of correlations $<\mathbf{0 . 0 1}$ ).
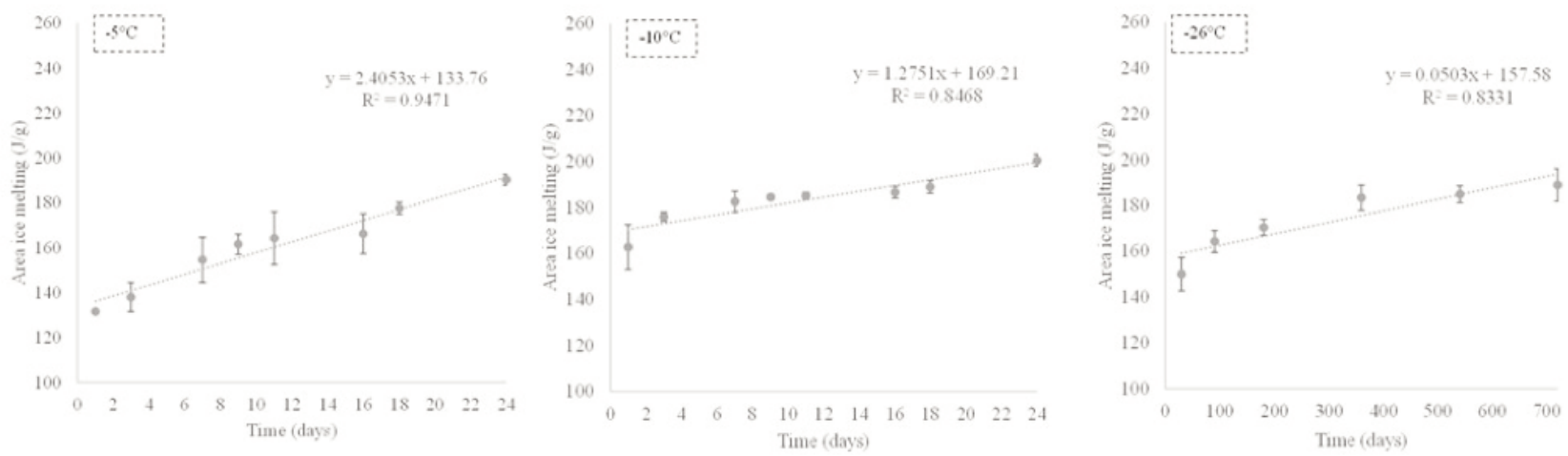

Figure 7. Heat of ice melting $(\mathrm{J} / \mathrm{g})$ kinetics of parsley samples as a function of storage time and temperatures $\left(-5^{\circ} \mathrm{C},-10^{\circ} \mathrm{C},-26^{\circ} \mathrm{C}\right)(\mathrm{p}-$ level of coefficients $<0.05$, p-level of correlations $<0.01$ ). 
general, the fitting of thermal data showed higher $\mathrm{R}^{2}$ and lower RMSE values with respect to those observed for the mechanical property measurements, probably due to smaller data variability of the first.

For each sample stored at the different temperatures, a zeroorder kinetic model was used to calculate their shelf-life by means of the obtained reaction rates and the $Q$-index to evaluate temperature dependence of the considered quality parameters between $5^{\circ} \mathrm{C}$ and $-26^{\circ} \mathrm{C}$ and $-10^{\circ} \mathrm{C}$ and $-26^{\circ} \mathrm{C}$. The Ats values were defined as the measured parameter at the end of the standard storage condition $\left(24\right.$ months at $\left.-26^{\circ} \mathrm{C}\right)$.

Shelf-life (days, Eq. 4) and $Q$-index calculated on the basis of $k$ rate values (Eq. 5) and shelf-life time (Eq. 6) are reported in Table 2. As expected, $k$ values decrease as a function of the storage temperature drop, consequently a noticeable shelf life-time reduction was found when the products were stored at higher temperatures. The only exception was for the $k$ values of heat of fusion of ice melting of spinach sample, where the $\mathrm{k}$ value at $-5^{\circ} \mathrm{C}$ was lower than at $-10^{\circ} \mathrm{C}$. This result is probably due to experimental errors connected to complex matrices such as foodstuffs. However, data at $-5^{\circ} \mathrm{C}$ are important and useful for the shelf-life estimation of frozen foods in misused thermal conditions. In the

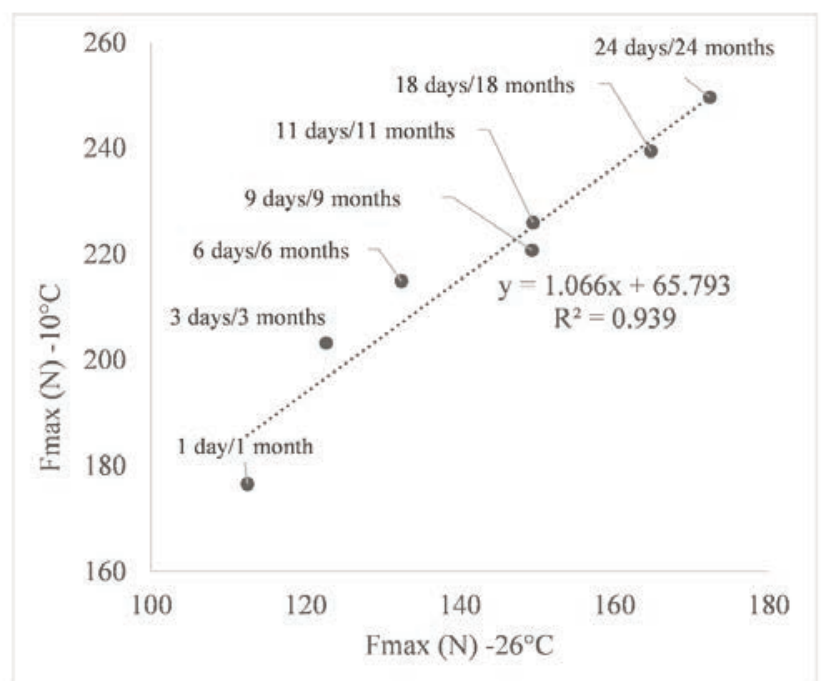

Figure 8 Linear regression between maximum force values of spinach at $-10^{\circ} \mathrm{C}$ and $-26^{\circ} \mathrm{C}$ at different storage time.

Table 1. Determination coefficient $\left(\mathbf{R}^{2}\right)$, root mean square error (RMSE), and variability of parameters $(\Delta)$ from linear kinetic physical data analysis of spinach and parsley samples stored at the selected temperatures.

\begin{tabular}{|c|c|c|c|c|c|}
\hline Sample & Physical parameter & Temperatures & $\Delta$ parameter & $\mathbf{R}^{2}$ & RMSE \\
\hline Spinach & $\begin{array}{l}\text { Heat of fusion of ice melting (unclear: maybe heat of ice fusion) }(\mathrm{J} / \mathrm{g}) \\
\text { Maximum compression force }(\mathrm{N})\end{array}$ & $\begin{array}{l}-5^{\circ} \mathrm{C} \\
-10^{\circ} \mathrm{C} \\
-26^{\circ} \mathrm{C} \\
-5^{\circ} \mathrm{C} \\
-10^{\circ} \mathrm{C} \\
-26^{\circ} \mathrm{C}\end{array}$ & $\begin{array}{l}34.75 \\
54.00 \\
86.20 \\
73.53 \\
59.88 \\
73.11\end{array}$ & $\begin{array}{l}0.881 \\
0.902 \\
0.954 \\
0.887 \\
0.929 \\
0.897\end{array}$ & $\begin{array}{l}4.07 \\
5.18 \\
5.99 \\
8.55 \\
5.05 \\
8.58\end{array}$ \\
\hline Parsley & $\begin{array}{l}\text { Heat of fusion of ice melting }(\mathrm{J} / \mathrm{g}) \\
\text { Maximum compression force }(\mathrm{N})\end{array}$ & $\begin{array}{c}-5^{\circ} \mathrm{C} \\
-10^{\circ} \mathrm{C} \\
-26^{\circ} \mathrm{C} \\
-5^{\circ} \mathrm{C} \\
-10^{\circ} \mathrm{C} \\
-26^{\circ} \mathrm{C}\end{array}$ & $\begin{array}{l}58.75 \\
37.75 \\
38.91 \\
86.32 \\
76.75 \\
74.99\end{array}$ & $\begin{array}{l}0.947 \\
0.847 \\
0.833 \\
0.903 \\
0.906 \\
0.915\end{array}$ & $\begin{array}{l}4.15 \\
3.95 \\
5.34 \\
9.41 \\
8.75 \\
8.57\end{array}$ \\
\hline
\end{tabular}

Table 2. Estimation of shelf-life and $Q$ values $\left(Q_{A k}, Q_{A t s}\right)$ from linear kinetic physical data analysis of spinach and parsley samples stored at the selected temperatures.

\begin{tabular}{|c|c|c|c|c|c|c|}
\hline Sample & Physical parameter & Temperature & $k$ & Shelf-life time (days) & & \\
\hline & & & & & $Q_{A k}$ (Eq. & $\mathrm{Q}_{\text {Ats }}(\mathrm{Eq} .6)$ \\
\hline Spinach & Heat of fusion of ice melting $(\mathrm{J} / \mathrm{g})$ & $-5^{\circ} \mathrm{C}$ & 1.517 & 38 & 3.59 & 4.33 \\
\hline & & $-10^{\circ} \mathrm{C}$ & 2.153 & 37 & 6.67 & 6.95 \\
\hline & & $-26^{\circ} \mathrm{C}$ & 0.103 & 823 & - & - \\
\hline & Maximum compression force $(\mathrm{N})$ & $-5^{\circ} \mathrm{C}$ & 3.216 & 22 & 5.50 & 5.61 \\
\hline & & $-10^{\circ} \mathrm{C}$ & 2.583 & 27 & 8.16 & 8.47 \\
\hline & & $-26^{\circ} \mathrm{C}$ & 0.090 & 824 & & \\
\hline Parsley & Heat of fusion of ice melting $(\mathrm{J} / \mathrm{g})$ & $-5^{\circ} \mathrm{C}$ & 2.405 & 21 & 6.31 & 5.64 \\
\hline & & $-10^{\circ} \mathrm{C}$ & 1.275 & 31 & 7.54 & 7.60 \\
\hline & & $-26^{\circ} \mathrm{C}$ & 0.050 & 795 & - & - \\
\hline & Maximum compression force $(\mathrm{N})$ & $-5^{\circ} \mathrm{C}$ & 3.921 & 23 & 5.70 & 5.39 \\
\hline & & $-10^{\circ} \mathrm{C}$ & 3.721 & 24 & 9.51 & 8.88 \\
\hline & & $-26^{\circ} \mathrm{C}$ & 0.101 & 790 & - & - \\
\hline
\end{tabular}

*QA values between $-5^{\circ}$ and $-26^{\circ} \mathrm{C}$ as $\mathrm{Q} 21$ and between $-10^{\circ}$ and $-26^{\circ} \mathrm{C}$ as $\mathrm{Q} 16$. 
Table 3. Linear regression among storage temperatures for thermal and mechanical parameters of spinach and parsley; $m$ is the slope of linear regression $(\mathrm{p}$-level $<0.05)$.

\begin{tabular}{|c|c|c|c|c|}
\hline Sample & Physical parameter & Temperatures & $m$ slope & $\mathbf{R}^{2}$ \\
\hline Spinach & $\begin{array}{l}\text { Heat of fusion of ice melting }(\mathrm{J} / \mathrm{g}) \\
\text { Maximum compression force }(\mathrm{N})\end{array}$ & $\begin{array}{l}-5 \text { and }-10^{\circ} \mathrm{C} \\
-10 \text { and }-26^{\circ} \mathrm{C} \\
-5 \text { and }-26^{\circ} \mathrm{C} \\
-5 \text { and }-10^{\circ} \mathrm{C} \\
-10 \text { and }-26^{\circ} \mathrm{C} \\
-5 \text { and }-26^{\circ} \mathrm{C}\end{array}$ & $\begin{array}{l}0.991 \\
0.704 \\
0.440 \\
0.735 \\
1.066 \\
0.824\end{array}$ & $\begin{array}{l}0.900 \\
0.903 \\
0.852 \\
0.877 \\
0.939 \\
0.910\end{array}$ \\
\hline Parsley & $\begin{array}{l}\text { Heat of fusion of ice melting }(\mathrm{J} / \mathrm{g}) \\
\text { Maximum compression force (N) }\end{array}$ & $\begin{array}{c}-5 \text { and }-10^{\circ} \mathrm{C} \\
-10 \text { and }-26^{\circ} \mathrm{C} \\
-5 \text { and }-26^{\circ} \mathrm{C} \\
-5 \text { and }-10^{\circ} \mathrm{C} \\
-10 \text { and }-26^{\circ} \mathrm{C} \\
-5 \text { and }-26^{\circ} \mathrm{C}\end{array}$ & $\begin{array}{l}1.708 \\
0.630 \\
0.813 \\
0.917 \\
0.694 \\
0.761\end{array}$ & $\begin{array}{l}0.917 \\
0.935 \\
0.937 \\
0.938 \\
0.927 \\
0.982\end{array}$ \\
\hline
\end{tabular}

development of new frozen products including reformulated ones or when changing packaging or storage/distribution conditions, the knowledge of product shelf life is an important aspect to be considered. It is known in fact that all the quality deterioration phenomena can have a complex behaviour due to fluctuating timetemperature conditions during storage/distribution (Dermesonluoglu et al., 2015). Accordingly, an extended temperature range, such as between $-5^{\circ} \mathrm{C}$ and $-26^{\circ} \mathrm{C}$ should be considered to understand and prevent possible modifications due to thermal abuse conditions. Typical $Q 10$ values for frozen foods range from 2 to 20 . This huge variability depends on food types, measured parameters and temperatures investigated (Fu and Labuza, 2000). The obtained $Q$ values (Table 2) for considered $\Delta T S$ of $16^{\circ} \mathrm{C}$ and $21^{\circ} \mathrm{C}$ are in good agreement with those reported in literature for frozen foods. Both spinach and parsley $Q$-indexes were from 6.7 to 9.51 considering both parameters at a $\Delta T S$ of $16^{\circ} \mathrm{C}$ and from 3.59 to 6.31 at a $\triangle T s$ of $21^{\circ} \mathrm{C}$.

Consequently, the accelerated tests for different temperatures proved useful to describe the evolution of parameters and linear regressions were calculated to relate parameter values obtained at different temperatures. Table 3 reports the estimated parameters of the linear models and related determination coefficients.

For both products, the high $\mathrm{R}^{2}$ values (from 0.852 to 0.982 ) indicate that there are strong linear relations for all temperature pairs, regardless of the investigated parameters.

The strong linear relation suggests an efficient procedure for shelf-life estimation by setting test condition as a function of this workable linear proportion. For example, Figure 8 shows a linear model between maximum force values measured at $-10^{\circ} \mathrm{C}$ and $26^{\circ} \mathrm{C}$. One day at $-10^{\circ} \mathrm{C}$ (as well as $-5^{\circ} \mathrm{C}$ ) could be considered equivalent to 30 days at $-26^{\circ} \mathrm{C}$. Accordingly, carrying out the test at $-10^{\circ} \mathrm{C}$ or $-5^{\circ} \mathrm{C}$ for one month and for the same period of time at $-26^{\circ} \mathrm{C}$ makes it possible to calculate the shelf life in a very short time.

The calculated $Q$-index of the tested hypothesis is 8.38 and is comparable to the values ranging from 6.95 to 8.88 . The order of magnitude of the expected $Q$-index, compared to the experimental ones confirms the proposed hypothesis.

\section{Conclusions}

A simple approach to estimate shelf-life of frozen spinach and parsley was presented. The change of some mechanical and thermal properties was useful to describe the reaction rates of related decay phenomena of the frozen vegetables during storage at differ- ent temperatures, and thus to calculate their shelf-life. The relation among the investigated frozen temperatures suggests a practical and fast procedure to assess shelf-life on the basis of $Q$-index: one day at $-10^{\circ} \mathrm{C}$ correspond to 30 days at $-26^{\circ} \mathrm{C}$. The $Q$-index of the proposed hypothesis is comparable to the one observed in the measured parameters, thus confirming the proposed relation.

The method is time-saving and very easy for assessing the shelf life of food products undergoing quality depletion which proceeds slowly under actual storage conditions (e.g. frozen, shelf-stable ones). Further products and even more temperature levels will be investigated using a similar approach to confirm the feasibility of the proposed shelf-life assessment method.

\section{References}

Alabi K.P., Zhu Z., Sun D.W. 2020. Transport phenomena and their effect on microstructure of frozen fruits and vegetables. Trends Food Sci. Technol. 101:63-72.

Correa A.R., Quicazan M.C., Hernandez C.E. 2015. Modelling the shelf-life of apple products according to their water activity. Chem. Eng. Trans. 43:199-204.

Dermesonluoglu E., Katsaros G., Tsevdou M., Giannakourou M., Taoukis P. 2015. Kinetic study of quality indices and shelf life modelling of frozen spinach under dynamic conditions of the cold chain. J. Food Eng. 148:13-23.

Fu B., Labuza T.P. 1997. Shelf-life testing: procedures and prediction methods.In: M.C. Erickson and Y.-C. Hung (Eds.), Quality in frozen food. Chapman and Hall, New York, NY, USA, pp 377-416.

George M., Gormley R. 2000. Managing the cold chain for quality and safety. Europe 5-33.

Giannakourou M.C., Taoukis P.S. 2019. Meta-analysis of kinetic parameter uncertainty on shelf life prediction in the frozen fruits and vegetable chain. Food Eng. Rev. 11:14-28.

Gonçalves E.M., Abreu M., Pinheiro J., Brandão T.R.S., Silva C.L.M. 2020. Quality changes of carrots under different frozen storage conditions: a kinetic study. J. Food Process. Preserv. 44:1-11.

Góral D., Kluza F. 2009. Cutting test application to general assessment of vegetable texture changes caused by freezing. J. Food Eng. 95:346-51.

Gormley R., Walshe T., Hussey K., Butler F. 2002. The effect of fluctuating vs. constant frozen storage temperature regimes on some quality parameters of selected food products. LWT - 
Food Sci. Technol. 35:190-200.

Iaccheri E., Cevoli C., Dalla Rosa M., Fabbri A. 2021. Thermophysical properties of frozen parsley: A state diagram representation. J. Food Process Eng. 1-7.

Labuza T.P., Fu B. 1993. Growth kinetics for shelf-life prediction: theory and practice. J. Ind. Microbiol. 12:309-23.

Li X.X., Zhao J.H., Zhang Y., Xiao H.W., Sablani S.S., Qu T.T., Tang X.M. 2020. Quality changes of frozen mango with regard to water mobility and ice crystals during frozen storage. J. Food Process Eng. 43:13508.

Martins R.C., Lopes I.C., Silva C.L.M. 2005. Accelerated life testing of frozen green beans (Phaseolus vulgaris, L.) quality loss kinetics: colour and starch. J. Food Eng. 67:339-46.

Mattetti M., Maraldi M., Sedoni E., Molari G. 2019. Optimal criteria for durability test of stepped transmissions of agricultural tractors. Biosyst. Eng. 178:145-55.

Mizrahi S. 2011. 15 - Accelerated shelf life testing of foods. In: D. Kilcast, P. Subramaniam (Eds.), Woodhead Publishing series in food science, technology and nutrition - Food and beverage stability and shelf life. Woodhead Publishing, Ltd., Sawston, UK, pp. 482-506.

Modarres M., Amiri M., Jackson C. 2017. Probabilistic physics of failure approach to reliability. Woodhead Publishing, Ltd., Sawston, UK.

Myer K. 2016. Handbook of environmental engineering. Choice
Reviews Online. Available from: https://doi.org/ 10.5860/choice. 195878

Roos Y.H. 2012. Materials science of freezing and frozen foods. Food Mater. Sci. Eng. 373-86.

Sahari M.A., Boostani F.M., Hamidi E.Z. 2004. Effect of low temperature on the ascorbic acid content and quality characteristics of frozen strawberry. Food Chem. 86:357-63.

Taoukis P.S., Giannakourou M.C. 2018. Modelling food quality. Food Sci. Technol. 32:38-43.

Telis V.R.N., Sobral P.J.D.A., Telis-Romero J. 2006. Sorption isotherm, glass transitions and state diagram for freeze-dried plum skin and pulp. Food Sci. Technol. Int. 12:181-7.

Tsironi T., Dermesonlouoglou E., Giannakourou M., Taoukis P. 2009. Shelf life modelling of frozen shrimp at variable temperature conditions. LWT - Food Sci. Technol. 42:664-71.

Ullah J., Takhar P.S., Sablani S.S. 2014. Effect of temperature fluctuations on ice-crystal growth in frozen potatoes during storage. LWT - Food Sci. Technol. 59:1186-90.

Van Boekel M.A.J.S. 2008. Kinetic modeling of food quality: a critical review. Compr. Rev. Food Sci. Food Saf. 7:144-58.

Vicent V., Ndoye F.T., Verboven P., Nicolaï B., Alvarez G. 2019. Effect of dynamic storage temperatures on the microstructure of frozen carrot imaged using X-ray micro-CT. J. Food Eng. 246:232-41. 